\title{
Arja Puurula
}

\section{Taiteet ovat sivilisaation kieli ja voima}

"Astuin reviirillesi, anteeksi”, sanoi Kansanvalistusseuran vuoden 2001 palkinnonsaaja, professori KARI UUSIKYLÄ ja kertoo televisio-ohjelmasta, jossa häntä haastateltiin taito- ja taidekasvatuksen jamasta kouluissa. Olen tyytyväinen, että luovuustutkija puolustaa taidekasvatusta. Viis reviireistä: kaikkien kasvatustieteilijöiden tärkein julkisuustehtävä on ravistaa kansakuntaa ja päättäjiä sillä oppineisuudella, sytyttävyydellä ja tutkimustietoudella, joka heillä on hallussaan. Kaappiteoreetikkoja tiede ei kaipaa.

Keskustelu taidekasvatuksesta on vyörynyt vilkkaana sen jälkeen, kun ehdotus peruskoulun uudesta tuntijaosta annettiin keväällä. Aktiivisimpia ovat olleet kuvataiteen opettajat, joiden pelko opetustehtävien vähenemisestä on todellista. Sama koettiin vuonna 1985, jolloin musiikin ja kuvaamataidontunnit tulivat valinnaisiksi yläasteella ja vain kuviksesta sai lisäpisteitä useaan jatko-opiskelupaikkaan. Seurauksena oli pätevien musiikinopettajien kato kouluista ja virkojen lakkauttaminen. Trendi jatkui 1994 uudistuksessa, joka romahdutti taideaineiden yhteisen opetuksen määrän ja siirsi näitä valinnaisaineiksi. Nyt keskimäärin joka kolmas kuvataide- ja musiikinopettaja on epäpätevä, haja-asutusalueilla huomattavasti useampi. Suomi on jakautunut kahteen taidekasvatuksen valtakuntaan, hyväonnisiin kulttuurin sampoihin ja viivottimilla taiteileviin tyhjätaskuihin.

Kulttuurikasvatusta tulisi tarkastella laajakantoisena, koko aikuiselämään vaikuttavana ratkaisuna. Mistä oppiaineiden valinnan vapaudesta sekin kertoo, että lauantai-illan pikagallupin, Napakympin, kolmesta urhosta kaksi toivoo osaavansa soittaa jotakin instrumenttia? Kansalaisopistojen kurssit pullistelevat vuosi toisensa jälkeen kaikkien alojen taiteenharrastajia, kesäkurssit ja taiteen kesätapahtumat kasvattavat suosiotaan. Suomalaiset ovat kansainvälisissä tilastoissa huippuluokkaa teattereissa, taidemuseoissa ja konserteissa kävijöinä.

Kuitenkin vuonna 1995 vain 31 prosenttia aikuisväestöstä piti taideaineita tärkeinä koulun oppilaineina. Määrä oli OECD-maiden alhaisimpia. Toisen tutkimuksen mukaan suomalainen musiikinopetus oli kouluaikana ollut yhtä teoreettista kuin matematiikan opetus, kuvataiteet selvisivät hieman paremmin. Kolmannen tutkimuksen mukaan joka toisella luokanopettajaksi opiskelevalla miehellä on kielteisiä muistikuvia musiikin opetuksesta, eivätkä he haluaisi opettaa tätä ainetta. Tässäpä haastetta opettajankouluttajille ja alan tutkijoille! Ratkaisu ei voi olla se, että taito- ja taideaineita vähennetään.

Galluptiedot eivät onneksi ole ikuisia. Ihmisten mielipiteet seuraavat julkista keskustelua. Ajankohtaisiin asioihin reagoidaan omalla kannanotolla ja tilannearvioinneilla. Taisipa Suomen Kuvalehti julkaista loppukesästä mielipidemittauksen, jonka mukaan joka toinen aikuisiässä oleva piti taidekasvatusta tärkeänä oppiaineena kouluissa. Kouluopetusta on myös uudistettu niin musiikissa, käsitöissä kuin kuvataiteissa sitten kuusikymmenluvun.

"Henkilökohtaisesti minulla ei ole mitään sitä vastaan, että musiikkia olisi toinenkin tunti yläasteella ja että taideaineita olisi kaikilla luokilla", sanoi ministeri Maija Rask lokakuussa Keravalla. Miksi puheet ja teot kulkevat eri tahtisesti? Tiedon vai näkemyksen puutetta? Valmistelevien virkamiesten kouluaikaisten muistikuvien heijastusta? Vinoutumaa arviointiraporttien ja työelämän tulevaisuusskenaarioiden lukemisessa? Taito- ja taidekasvatus vaatisi Suomessa kokonaisvaltaisen, sekä koulun ja taiteen perusopetusjärjestelmän, niin aikuisiän kuin työelämän tarpeita koskevan selvityksen.

Kulttuuri oli merkittävä työllistäjä jo 90-luvun lopulla. Laman aikana se oli ainoita aloja, joiden työllisyys kasvoi. Kulttuurialoilla toimivien määrän ennustetaan kasvavan tulevassa "luovuusyhteiskunnassa". Tai kuten amerikkalainen taidekasvatuksen puolestapuhuja, CHARLESS FowLER, kirjoitti: "Taiteet ovat sivilisaation kieli ja keskeinen voima ihmiskunnan olemassaololle." 